\title{
Mani (216-276 CE) and Ethiopian Enoch
}

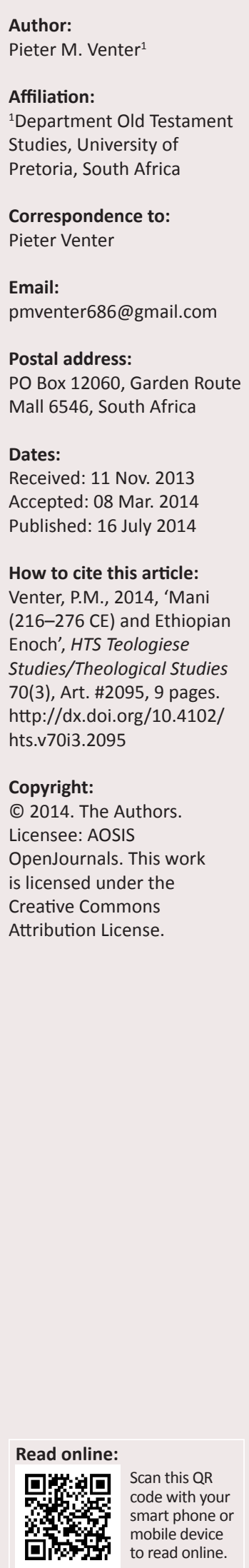

Mani (216-276 CE) lived in a world where many ideas contributed to his unique theology. In the scriptural legacy of Mani seven of his books show influence of Ethiopian Enoch. These books are identified in this article and the use of Enochic material in those books is discussed. The Manichaean myth is briefly discussed and used to propose that Enochic influence can mainly be found in the way First Enoch depicted characters and presented the cosmos. Mani adopted his ideas mainly from the Book of the Watchers (1 En 1-36), the Book of Parables (1 En 37-71) and the Astronomical Book of Enoch (72-82) where evil beings and cursed places are depicted.

\section{Introduction}

Mani (216-276 CE) was the founder of Manichaeism. This religion developed out of the JewishChristian Elchasaite ${ }^{1}$ group. It spread out to North Africa, Egypt, Central Asia, Oxus in the east, and as far east as China.

Mani was a prolific writer. His legacy reflects the circumstances under Sasanian Rule in the east during the 3rd century CE (cf. Baker-Brian 2011:3). He used ideas and phrases from his surroundings to gradually formulate a Manichaean theology. He also used allusions and motifs from Ethiopian Enoch. This article studies those books attributed to Mani that reflect the use of Ethiopian material. The relevant material is identified and existing research results regarding the use of Enochic material surveyed. Mani's myth is briefly summarised and the probable reasons for Mani's interest in Enochic ideas investigated. It is proposed that Enoch's depiction of two classes of men - righteous and evildoers - and his phantasmagorical cosmology was adopted from Enochic material and adapted by Mani for his works.

\section{Mani's works}

Mani's literary legacy ${ }^{2}$ can be divided into three parts: his 'Shabuhragan', the Manichaean canon, and some other works by Mani. The 'Shabuhragan' is the oldest book attributed to Mani. The Manichaean canon ${ }^{3}$ comprises 'The living Gospel', 'Treasury of life', 'Pragmateia', 'Book of Mysteries', 'Book of Giants', 'Epistles' and 'Psalms-Prayers'. The other works are Mani's Kephalia, the Codex Manichaicus Coloniensis (CMC) and the Triumph of Light (Klimkeit 1993: text 8). From Mani's 'Shabuhragan', his 'Treasury of life', the 'Book of Mysteries', the 'Book of Giants', the Codex Manichaicus Coloniensis (CMC), and the Triumph of Light (text 8) can be linked to Ethiopian Enoch and are therefore of concern for this study.

\section{Use of Enochic material in Mani's works ${ }^{4}$}

There was 'a literary nexus between scribal circles of Second Temple Judea ... and subsequent Syro-Mesopotamian gnostic movements, including Manichaeism' (Reeves 1999:157). Due to the

1.'[A] sect known as the "Mughtasilah" that is: those who wash (or: baptise) themselves' (Van Oort 2009:126). Community of the Mughtasilah was instituted by a certain al-Hâsîh, a Jewish-Christian prophet said to have lived at the beginning of the second century' (Van Oort 2009:127). According to Tardieu (2008:8) Elchasaitic Christianity regarded Jesus as the last of a series of Christs or messiahs. They were 'Judeo-Christian in the strict sense: a Christian practicing the kind of Jewish life that had been fixed once and for all by the prescriptions of The Torah.' Elchasaite baptism practiced strict maintenance of the Mosaic laws in their own fashion (cf. Tardieu 2008:19). At the beginning of the 2nd century CE 'Elchasaitic Judeo-Christianity was firmly established in Transjordan and very active in Arabia' (Tardieu 2008:8). Following Paul, Mani broke away from this type of Jewish legalism, although he was well schooled in their ideology.

2.Baker-Brian (2011:10) makes a very important distinction between the body of Mani's 3rd-century teachings and the cultural translation of these teachings during the course of the religion he founded. His teachings were transformed by his followers 'into a religion with an institutional structure over time, and in historical circumstances different from those encountered by Mani during the initial formulation of his own theology' (Baker-Brian 2011:24). Soon after Mani's death the tendency arose 'to idealise all aspects of his life, but in particular of his childhood and early adulthood' (Baker-Brian 2011:37). Sundermann (1992:45) referred to 'the proviso that the teaching of the founder of a sect can be subject to modification in actual practice among his followers'.

3.According to Tardieu (2008:48-49) the canon decision on which Manichaean literature was to be admitted into a closed collection of sacred works 'seems to have been taken following Mani's death under the pontificate of Sis, in keeping with the founder's wishes, and until quite late in its history it was regarded as sacrosanct.' Baker-Brian (2011:66) found the time and circumstances under which Mani's writings became fixed in a canon as something of a mystery. With the exclusion of the Shabuhragan, the Manichaean canon Mani's writings became fixed in a canon as something of a mystery. With the exclusion of the Shabuhragan, the Manichaean canon
was constituted as a seven-part collection. Baker-Brian (2011:66) points out that the Manichaean canon contains five books in some sources. Van Oort (2006:718) pointed out that Augustine's book of 395 CE addressed to Paulinus was explicitly 'directed against the Pentateuch of the Manichaeans who, for their part, had combined Mani's books into a Pentateuch directed against the Mosaic one'.

4 In Pettipiece's (2005:254) investigation into Mani's adoption and adaptation of other material he came to the conclusion in light of Mani's sense of superiority that 'the development of Mani's teaching was somewhere in between deliberate and instinctive'. Pettipiece (2005:247) focused in his article on the 'hindered reception' in the context of a variety of host cultures, rather than Mani's own reception of older material. 
widespread phenomenon of prophecy the 'dissemination of radical ways of reading and interpreting the scriptural substrata shared by Jews, Christian gnostics, and Muslims' lead to 'the transmission of narrative motif, exegetical traditions and even entire works across formal religious boundaries' (Reeves 1999:163). This variety of users of literature makes it problematic to decide how exactly Mani used older material.

Living in an area with 'the most varied religious traditions' (Klimkeit 1993:2) Mani had many different writings from Judaism, from Christianity, from Zoroastrianism and from Buddhism, Gnosticism and the Elchasaite library available to him. ${ }^{5}$ Amongst these Mani made use of the Enochic tradition as well. Nickelsburg (2001:99) even remarked: 'The apostle Mani (216-276 CE) perhaps more than any writer in antiquity, incorporated material from the Enochic writings into his religious system' (see Stroumsa 1984:152-167).

Two general remarks are to be made on Mani's use of biblical and pseudepigraphical material. Firstly, Reeves (1999:163, n. 63) remarked that 'the uniqueness of Mani's teaching about the aborted demons, fallen from heaven as creators of human beings, can be traced back to Jewish Enoch literature'. Secondly, Reeves (1994:174) also indicated that Manichaean texts rarely cite the Hebrew Bible, but use characters and events referred to in the Hebrew Bible 'particularly those within the primeval history of Genesis 1-11', which 'assume a major significance in the ideological development of Mani's thought'.

\section{Shabuhragan}

The Shabuhragan represents an earlier stage in Mani's teachings. Its text was only known in Asia Major, but widely disseminated there (cf. Klimkeit 1993:225). A substantial portion of that text is preserved in the original and still available to us (cf. Klimkeit 1993:225). This was the only book Mani wrote in Middle-Persian (cf. Hutter 1992:124). The book was intended to inform the Sasanian leader Shapur I of the fundamental insights of Mani's new religion. It was written somewhere between 240 and 250 CE (cf. Baker-Brian 2011:26).

Hutter (1992) edited and published the Middle-Persian manuscripts M 98/99 and M7980-7984. Hutter (1992:135) proposed that the Turfan manuscripts M 49 and M 299a could have been part of the first chapter of the Shabuhragan. Manuscript M 299a deals with the 'coming of the apostle'. It refers to the precursors of Mani amongst whom Enoch is pointed out. This is an indication for Hutter that Enochic literature 'teilweise in den Manichaismus übernommen wurde' [was partly taken over in Manichaeism] (1992:135).

In Shabuhragan Mani drew abundantly on synoptic pericopes on the end of the world and judgement and Pauline accounts of the Parousia from the New Testament

5.Sundermann (1993) remarked that " $[d]$ etails of the Manichean myth reveal greater similarities with the cosmogonic and anthropological teachings of Bardesanes than with Zoroastrianism, suggesting that he may have been the most significant source with Zoroastrianism, suggesting that he may have been the most significant source
of inspiration for Mani.' This reminds us that Mani used many more sources than of inspiration for Mani.
just Enochic literature. writings (cf. Tardieu 2008:34). He 'took up and developed Jewish and biblical imagery and symbolism, relating them to the symbolical and mythological languages of Persia in his Shabuhragan' (Klimkeit 1993:7). He also used some other writings as well, chiefly the Enoch Writings (cf. Tardieu 2008:34). Sundermann (1993) pointed out that the connection between the cosmogony and calendric speculations in Mani's work was stimulated by the Aramaic Enoch writings.

Remarkable resemblance exists between astronomic Turfan M 98 1, M 99 I and the Book of the Luminaries in Ethiopian Enoch 72-82 (cf. Baker-Brian 2011:28,76). W.B. Henning asked the question already in 1934 whether Ethiopic Enoch was the example for this manuscript. In the Astronomical Book of Enoch (1 En 72-82, also called the Book of the Luminaries) the elevated Enoch possessed and revealed cosmological and astronomical secrets. In 1 Enoch 72:1, 74:2, and 80:1, he is depicted as recipient of angelic revelations that included celestial knowledge of astronomical, meteorological, and calendric traditions. In 1 Enoch 41:1 Enoch is described as the one who 'saw all secrets of heaven'. In the majority of the materials associated with the early Enochic circle he is depicted in this capacity (cf. Orlov 2007:113).

Another motif borrowed from 1 Enoch 60:7-10 was pointed out by J.C. Reeves. The idea of a female monster dwelling in the depth of the ocean is found in both Mani and Enoch. Reeves suggested that the Enochic passage was probably the 'scriptural root of the Manichaean episode' (quoted by Hutter 1992:137).

Hutter's (1992) comparison of sections from the Shabuhragan with the literature of First Enoch brought him to the conclusion that Mani's original Persian document was deeply rooted in the Christian and Syrian world. Although Zoroastrian traditions cannot be denied, the Western influence cannot be ignored. The Enoch tradition was 'so gut integriert' [so well integrated] (Hutter 1992:139) in Mani's work that it can only be identified by expert literary knowledge. Klimkeit (1993:225) therefore warned against 'an overemphasis on this tradition at the cost of the Iranian, particularly the Zurvanite influence on Mani. ${ }^{6}$

\section{Iranian and Turkish texts}

In the Manichaean canon, the Pragmateia, the Book of Mysteries, and the Book of the Giants are grouped together. The Book of Mysteries makes extensive use of Christian and other apocryphal traditions. There are 18 chapters in this book (cf. Baker-Brian 2011:83). It was written in opposition to a book written by one Bardaisan (now lost) to supplant his ideas on 'the mysteries'.

Tardieu (2008:39) was of the opinion that this book 'is perhaps an exegesis of a fragment of the Apocalypse of Enoch'.

6. Heuser and Klimkeit (1998:251) remarked that "even Iranian mythology was included, though transformed, to fit the new system.' From the Iranian religion of Sasanian Persia many images and narrative motifs were incorporated into the Manichaean system. They even adopted Western narrative materials like the fables Manichaean system. They even adopted Western narrative materials like the fables
of Aesop, stories from the Iranian world, and fragments of the Indian Pancatantra cycle. 
According to Baker-Brian (2011:85) Mani contextualised 'pseudepigraphic writings ascribed to Enoch and Adam, in their roles as apostles of light' to substantiate his claim to be 'at the end-point of the line of divinely-sanctioned apostles.' In Klimkeit's (1993) translation and presentation of Iranian and Turkish Gnostic texts remarkable agreements with the Enochic literature can be found. Reeves (1994:197) indicated that the Book of Mysteries gives a clear demonstration of Mani's use of Jewish Enochic traditions, particularly the legends of the Watchers and the Giants in 1 Enoch 6-11. Baker-Brian (2011) remarked:

[I]t should also be noted that Mani appears in this work to have been concerned with providing only the legendary material surrounding the Beginning and Middle times of the Manichaean periodization of the cosmos. (p. 82)

In the section 'The Three Trenches' of the Book of Mysteries a series of cosmological pits dug around the world into which the demonic waste of the firmaments is poured, reminds one of 1 Enoch 22. An obvious agreement between the hollow places can be noted, where the spirit of the souls of the dead are kept (1 En 22:1-3), and the reference to the Prince of Darkness who has subjugated 'the five pits of death' in Triumph of Light (text 8) (cf. Klimkeit 1993:35). In the Persian texts of Mani's accounts of the making of the world (cf. Klimkeit 1993:225) the 'three pillars and five arches facing the east, south and west' remind strongly of the depiction of the earth in Enoch's Third Journey (1 En 20-36). The same is true of the Persian Text A's discourse on that which is material (Klimkeit 1993:227-228). The Living Spirit made and ordered 'four layers, the prison of the demons, and the four earths with (their) columns, structures, portals, walls, ditches' (Klimkeit 1993:227).

The 'Treasury of Life' consisted originally of seven books (cf. Baker-Brian 2011:79). Only a limited number of fragments still exist - they deal with elements of Mani's cosmogonic teachings (cf. Baker-Brian 2011:79).

\section{The Book of the Giants}

About a dozen fragments of Mani's Book of Giants, written in Middle Persian, Sogdian, and Uighur, were found in Turfan (cf. Klimkeit 1993:247). Henning (1943) published two Iranian fragments of Mani's Book of the Giants in 1934 - these fragments confirm that Mani wrote a Book of the Giants.?

However, another Book of Giants was found elsewhere. Nine of the twenty Aramaic Enoch fragments found at Qumran since 1947 contain sections of an Aramaic Book of the Giants. These fragments date from the first half of the 1st century BCE to the early 1st century CE (cf. Nickelsburg 2001:76). These manuscripts reflect only parts of a work narrating the activities and fortune of the heavenly watchers and earthly women. However, the fragmentary condition of these manuscripts 'hinders certain conclusions about the precise relationship of this work to components of 1 Enoch' (Nickelsburg 2001:173).

7.Sundermann (2001) said the Book of the Giants is 'a book mentioned as a canonical work of Mani in the Coptic Kephalaia (chap. 148), in the book of Homilies (p. 25.3$4)$, and the Psalms (p. 46.29)'.
The 'subject matter of the Book of Giants relates to the core myth in 1 Enoch 6-11', whilst 'its narrative details are strikingly similar to elements in the broader Enochic elaboration in various parts of 1 Enoch' (Nickelsburg 2001:173). The issue to be addressed here, therefore, is the relationship between these Aramaic fragments of a probably older Book of Giants found at Qumran and what is known as 1 Enoch's Book of the Watchers (1 En 1-37), especially the narrative of the rebellion of the Watchers in 1 Enoch 6-11.

Furthermore, not only a question has to be posed about the relationship of these Aramaic fragments with the Enochic Book of the Giants in 1 Enoch 6-11, but also as to the relation between this Aramaic Book of the Giants and Mani's Book of Giants.

Mani's Book of Giants is 'a political pamphlet in the guise of allegory and myth' (Tardieu 2008:47). In this book Mani transformed well-known existing material from the Second Temple period of Jewish history 'into an extended discourse on the related issues of cosmogony and the nature of evil' (Baker-Brian 2011:86). Reeves (1992:88) postulated that 'religious personae or concepts were freely shared amongst the Jewish, Christian, and Mandaean communities'. Stories in a Book of Giants and the Midrash are 'textual expressions of an early exegetical tradition circulating in learned groups during the Second Temple era' (Reeves 1992:88). This tradition was used by Mani to create a cycle of fabulous narratives, relating to 'an independent account that relates, with a great many details and proper names, the amorous and dramatic adventures of the fallen angels and their terrestrial progeny, the giants' (Tardieu 2008:46).

J.T. Milik (1976:298-339) suggested that the Aramaic Enoch was the primary source utilised by Mani in the compilation of his Book of the Giants (cf. Reeves 1992:3). Hutter (1992:7) remarked that not only the person of Enoch, but also the Enochic literature played a major role in Mani's works. He is of the opinion that this can be illustrated in Mani's Book of the Giants. According to Baker-Brian (2011:86) Mani's book was a 'creative reimagining of one of the principal components (the 'Book of the Watchers') of the work known as 1 Enoch'. He speculated that the Enochic literature, and specifically a version of the Qumranic Book of Giants used by Mani was already part of the Elchasaite canon of scriptural texts with which Mani grew up (cf. also Tardieu 2008:46).

To Reeves (1992:127) it 'is clear that Mani had access to a copy or later recension of the Qumran text. ${ }^{8}$ His theory therefore, was 'that the Manichaean Book of Giants was based, at least in part, upon a text very similar to that recovered from Qumran. ${ }^{\prime 9}$ Klimkeit (1993:247) agreed with Reeves that 'this

8.It seemed plausible to Reeves (1992:208) to conclude that Mani encountered the [Qumran] Book of Giants during his sojourn amongst the Elchasaites. The Elchasaite reverence for the forefathers probably included writings ascribed to Enoch. Compare also Baker-Brian (2011:86) for the same theory. Sundermann (2009) also proposed that 'parts of the Enoch literature found their way into the Christian tradition, and so it is likely that Mani became familiar with the Jewish Book of the Giants in his paternal Elkhasaite community'. He used this material to write his Book of the Giants.

9.It is probable that an older Giant tradition is intended. Mani used this tradition for his book and an Enochic tradition was used for the Aramaic book or the tradition. The theory more generally held is that Mani used the Aramaic tradition. Sunderman (2001) counts amongst those who see the Jewish Book of Glants, later replaced in the Christian Enoch tradition by a Book of Parables, as the main source of Mani's Book of Giants. According to him this is proven by textual comparisons and the similarity or correspondence of many names. 
book of Mani's was based on an ancient Jewish Book of Giants, originally written in Aramaic' which was used at Qumran (cf. Baker-Brian 2011:86). The Enoch book was recognised as 'Vorlage zum manichäischen Gigantenbuch' [example text for the Manichaean Book of the Giants] (Hutter 1992:135; cf. also Milik 1971; Milik 1976; Reeves 1992; Sundermann 1984). Referring to J. Milik, Baker-Brian (2011:87) found it 'clear that an earlier, prototypical Book of Giants had been in existence'.

The fragmentary form of the available Aramaic Enoch manuscripts makes it difficult to research how Mani recycled a probable existing Giant traditum (in whatever form it was available to him) into a Giant tradition used by his followers in the form of a book. A very close relationship exists between Mani's Book of Giants and the story told in the Aramaic fragments. Issues like the continuity of narrative motifs, evil as consequences of the descent of the Watchers, the wickedness of their offspring, and the correct interpretation of dreams, indicate an intentional relationship between 'the earlier Jewish composition and the later Manichaean recension' (Reeves 1992:127). However, Reeves (1992:127) confirmed that 'Mani's Book of Giants is not merely a copy of the Qumran prototype'. In his book the battle between the angels above and those on earth is interspersed by allegorical observations (cf. Reeves 1992:127). Ideas like the dichotomy between heaven and earth, good and bad, the phenomenon of evil, mixture between two categories of creatures, and God's intervention, are also used in Mani's Giants, but within a different context. ${ }^{10}$

In Ethiopian Enoch (1 En 6-16) rebellious angels (the watchers) introduced evil into the realm of the earth. From the watchers' illicit sexual unions with the human women, giants were born. They brought riot throughout the world, murdered men, stole resources and destroyed all living creatures and the natural world (1 En 7:3-6). The watchers taught men about the destructive arts (1 En 8:1-3), like warfare, consumerism, magic and sophistry. These increased suffering, sin and impiety.

This idea of giants born from illegitimate contact between heavenly beings and human daughters corresponds with the legend of the 'sons of Elōhīm' who descended on earth, copulated with the daughters of men, and procreated a race of giants in Genesis 6:1-4. ${ }^{11}$ Sundermann (2009) proposed that this legend was elaborated in the Aramaic Book of the Giants and related works which were ascribed to Enoch. Fragments of this elaboration were discovered amongst the Qumran texts. This legend was taken up by Mani in his Book of the Giants, either from a separate 'sons of Elōhīm' legend reflected in Genesis 6:1-4, or from an existing Giant tradition used in parallel by Mani and the Enochic tradition, or via the Aramaic Giant tradition at Qumran as Sundermann (1992:43-46) proposed. ${ }^{12}$

10.Reeves (1992:128) raised the important question whether Mani had already formulated his ideas before he consulted the older Giant material, or was it the older material that had helped him in formulating the eventual Manichaean Myth?

11.Genesis 6:1-4 contains elements also found in 1 Enoch. Genesis 6:1-2 corresponds with 1 Enoch 6:1-2. Nickelsburg (2001:166) remarked that there is broad consensus with regard to the relationship between the two passages and the 'Enochic text is, in some sense, an interpretation of Genesis.'

12.Another issue with regard to older material in First Enoch is the theory of a Shemihazah myth underlying 1 Enoch 6:3-7 (cf. Nickelsburg 2001:165-168). Reed (2009:146) postulated an earlier form for 1 Enoch $6-11$. He did not choose any specific single form for the earlier stage, but remarked that the chapters of Enoch 'do resonate with Graeco-Roman traditions about culture-heroes.' This is probably what interested with Graeco-Roman traditions about culture-heroes.' This is probably what interes

\section{The Codex Manichaicus Coloniensis}

This is the 'earliest extant original Manichean work written in Greek' (Sundermann 1992:43) 'from fourth or fifth century Egypt' (Klimkeit 1993:2; cf. Heuser \& Klimkeit 1998:300). This very small uncial codex measuring $38 \mathrm{~mm} \times 45 \mathrm{~mm}$ is kept at the University of Cologne, hence its name 'Cologne Mani Codex' (CMC). ${ }^{13}$ The codex is badly damaged; particularly in its latter half (cf. Reeves 1996:5). Approximately 192 leaves have survived for present research.

In its present form the CMC is not the work of one single author, but comprises excerpts from the testimonies of Mani's closest disciples and early followers' (Van Oort 2009:127). Baker-Brian (2011:38-39) described the CMC 'as something more than a biography of Mani.' It reflects his followers' views on Mani as playing a 'role in the wider cosmic reality which he had expostulated during his lifetime' (Baker-Brian 2011:39). It is a 'compilation and redaction of the earliest testimonies of Mani's deeds and words' (Van Oort 2009:127). Sundermann (1992:45) remarked that the 'hope of finding in this text Mani's teachings in their original form, free of later ontological dualism, thus remains unfulfilled'. It provides information on Mani's formative years and how he emerged as an apostle.

W. Sundermann (1985, cf. 1984:491-505, 1989:67-79) investigated Fragment M 5900 of the CMC that refers to God's chastisement of the Giants. His study made it clear that Mani 'nicht nur die Gestalt Henochs kannte, sondern auch Teile der mit diesem Propheten verbundenen Literaturschatzte' [not only knew the figure of Enoch, but also valued sections linked to the prophet] (Sundermann 1985:55; cf. also Hutter 1992:136).

According to Reeves (1996) this document contributes to:

the dawning realization that there is a genetic linkage conceptual, ideological, and most importantly, literary between the intellectual circles of Second Temple and late antique heterodox Judaism ... and late antique Syrian and Mesopotamian syncretic currents. (p. 6)

In a period of vibrant literary activity, production and collection took place 'of a vast host of literary traditions surrounding the heroes of the national legends' (Reeves 1996:32) ${ }^{14}$ Citations from texts ${ }^{15}$ can be found here which have not been preserved. There was not always a strict adherence

13.Its original title is 'Perì tês génnēs toû sốmatos autoû' [On the origin of his body] (Sundermann 1992:44).

14. Heuser and Klimkeit (1998:121) refer to A. Böhlig's 1947 doctoral thesis on the Bible amongst the Manichaeans. This thesis was posthumously re-edited by Nagel and Richter in 2012 under the title of Die Bibel bei den Manichaern und verwandte and Richter in 2012 under the title of Die Bibel bei den Manichaern und verwandte
Studien. In his thesis Böhlig studied the Manichaeans's use of selected passages of Studien. In his thesis Böhlig studied the Manichaeans's use of selected passages of
the New Testament, especially of the Gospels and Pauline letters. The 'Manichaeans the New Testament, especially of the Gospels and Pauline letters. The 'Manichaeans and a Gospel harmony that had as two of its sources the Gospel of Peter, and the Gospel of Nicodemus' (Heuser \& Klimkeit 1998:121). Other 'Gospels known to them were the Gospel of Thomas, the Gospel of Philip and perhaps the Gospel of Eve' (Heuser \& Klimkeit 1998:121).

15.Frankfurter (1997:60) remarked that none of Mani's apocalyptic 'texts' referred to in CMC matches extant apocalypses in the name of Enoch, Adam, Seth, or Enosh. He proposed that Mani invented these sources to promote his revelation's ecumenical appeal. He cast himself in a line of biblical figures that in the late antique world had especially universalist significance. He revised existing schemes of Jewish revelatory heroes that were traditional to Jewish and Jewish-Christian sects. Frankfurter (1997:60) said: 'Mani's apocalyptic florilegium ... depends not on sects. Frankfurter (1997:60) said: 'Mani's apocalyptic florilegium ... depends not on
the historical existence of the putative texts but on Mani's own distinctive scheme the historical existence of the putative
of prophetic lineage and authority'. 
to the exact text of the biblical and apocryphal sources used and more or less free citations of such material can be found (cf. Heuser \& Klimkeit 1998:121).

Of importance for us are the quotations excerpted from five otherwise unknown Jewish pseudepigraphic apocalypses on leaves 45-72 of the CMC to marshal Mani's authenticity (cf. Reeves 1996:6). In these leaves Mani is identified with the divine raptures of the biblical forefathers Adam, Seth, Enosh, Shem and Enoch, depicting his revelatory teachings as pure prophetology (cf. Baker-Brian 2011:50-51). These forefathers were seen as predecessor 'heralds' authoring revelatory texts passed down from generation to generation (cf. Reeves 1996:33).

The Apocalypses of Enosh and the Apocalypse of Enoch are of concern for this study. Not corresponding textually to any previously-known works attributed to these authors, all of these apocalypses display a general similarity in their formal structure. According to Reeves (1994:176), ‘[e]ach citation is introduced as an "apocalypse" of the named author and each concludes with a notice about other "writings" supposedly authored by these seers.' Each case reports visionary experiences - angelophany - a vision of one or more angelic beings. Each seer is taken up to heaven and views certain sights there or is informed of certain secrets.

In his translation and commentary of these apocalypses Reeves (1996:39) indicated several correspondences with the Enoch tradition reconstructed from the available manuscripts at Qumran. ${ }^{16}$

\section{Apocalypse of Enosh}

Several features of the supernatural landscape visited by Enosh in his Apocalypse agree with those found in Enoch's third journey in 1 Enoch 20:1-36:4. Reeves (1996:141-161) referred to 1 Enoch 22:1-5, 24-25, 25:5, 32:1-3 and 34:1. According to Reeves (1994):

[ $t$ ] he topography of the supernal regions traversed by Enoch - a world of death, a world of darkness, a world of fire and a world of bright richness - would seem to reflect the divisions of Sheol viewed by Enoch in I Enoch 22, which constructs a schema of three dark and tortuous places for sinners alongside another for the righteous which contains a 'bright spring'. (p. 182)

All of this is especially found in the third of Enoch's journeys reported in 1 Enoch 12-36. Reeves (1994:180) referred to other sections of First Enoch as well: 1 Enoch 61:1-5, 70:2-3, 77:4, 77:7. The first two in 1 Enoch $61: 1-5$ and 70:2-3 belong to the Book of the Parables in (1 En 37-71), whilst the last two in 1 Enoch 77:4 and 7 belong to the section of the Book of the Luminaries, also called the Astronomical Book of Enoch (1 En 72-82). The relevant sections in Enoch's third

16. Reeves (1996:39) pointed out that the large quantity of quotations or allusions to Enochic books shows that Enochic compositions 'apparently circulated among learned circles during late antiquity well into the medieval period'. Next to fragments of earlier versions in Greek, Syriac, Coptic and Latin, the 'most important textual witnesses to the origin and growth of 1 Enoch were found amongst the Aramaic manuscripts recovered from Qumran, some of which may date to the third or even fourth century BCE' (Reeves 1996:39). Hutter (1992:135) referred
to CMC 'worin mehrfach aus einer Apokalypse des Henoch zitiert wird' [in which more than once quotations are made from an Apocalypse of Enoch]. It is not clear more than once quotations are made from an Apocalypse of Enoch]. It is not clear whether Mani's Apocalypse worked with an existing literary work attributed to
Enoch and, if so, at what stage of development the eventual Ethiopian Book of Enoch was at that time. journey in 1 Enoch 20:1-36:4 refer to the angel Raphael and a mountain with hollow places ${ }^{17}$ where the souls of the dead are kept (1 En 22:1-5), the mountain of God and the tree of life (1 En 24:2-25:7), the fragrant tree transplanted to the holy place (1 En 25:5), the tree of wisdom in the paradise in the east (1 En 32:1-3) and the ends of the earth in the north (1 En 34:1). In the Book of Parables (1 En 37-71) the story is told of the angels who prepare to gather the righteous (1 En 61:1-5) and Enoch is taken to paradise (1 En 70:2-3). Verses four and seven of 1 Enoch 77, deal with lofty mountains and rivers pouring into the sea. These allusions deal with either strange natural phenomena (mountains, hollow places, trees, rivers, wind directions), or the eschatological destiny of people, righteous or doomed, attached to these places.

Reeves (1994:182) conceded that no verbatim correspondence can be indicated, but obvious allusions to motifs and events found in 1 and 2 Enoch can be pointed out. He referred to several themes found in Mani as well as 1 Enoch. The Enosh fragment begins with the statement 'I am Enosh the righteous' - an epithet used as a stock feature in the Enochic literature. Michael plays the same role in Enosh as in 1 Enoch 71:52:

The specific reference to a 'chariot of wind' ... as Enosh's mode of conveyance in the CMC fragment in fact possesses a direct parallel in I Enoch 70:2, where Enoch is also raised to heaven through the agency of 'chariots of wind'. (Reeves 1994:182)

These correspondences cannot be ascribed to 'mere chance' (Reeves 1994:182).

Reeves (1994:183) came to the conclusion that Mani not only adopted and adapted an Aramaic 'Book of Giants', but also sections from what is now known as the 'Book of Watchers' (1 En 1-36), 'Book of Similitudes' (1 En 37-71) and the 'Astronomical Book' (1 En 72-82).

\section{Apocalypse of Enoch}

In the case of the Apocalypse of Enoch, Reeves's (1996:183-206) examination indicated a 'discernible influence of material now found only in the Similitudes of Enoch (1 Enoch 37-71) on the "apocalypse"' (Reeves 1996:197). For the compilation of the Apocalypse of Enoch textual traditions, motifs and patterns were used from the surviving Ethiopic and Slavonic books of Enoch. Four of the five books of the eventual Ethiopian Enoch are reflected in the Apocalypse. However, certain contents of the Parables ${ }^{18}$ described in the Apocalypse, 'particularly 17.The headings of Nickelsburg and VanderKam's 2004 translation are followed in this article.

18. Reeves (1996:197) indicated that the Apocalypse he studied shows closer agreement 'with the Aramaic Vorlage of 1 Enoch than with the subsequent Greek and Ethiopic versions'. This indicates that the Manichaean employment of 1 Enoch 'goes back to the earliest Mesopotamian stages of the group's formation,' even to Mani himself. However, the remarkable agreement with Enoch's Book of Parables presents the problem that nothing of the Book of Parables (Book of Similitudes) (1 En 37-71) was found at Qumran. There is no 'textual evidence for the existence of the Similitudes prior to the preparation of the Ethiopic version of 1 Enoch, which took place presumably during the fifth or sixth centuries CE' (Reeves 1996:197; cf. Nickelsburg 2001:21). This means that the Apocalypse was either written much later and added to CMC by somebody else, or, what Reeves proposed: the Book of later and added to CMC by somebody else, or, what Reeves proposed: the Book of Parables already existed during the 1st or early 2 nd century CE (cf. Reeves 1996:198) Nickelsburg (2001:76-77) suggested that the Book of the Parables 'was composed outside Qumran' in circles that transmitted the Book of the Watchers. The same arguments could have been raised by Reeves regarding the Book of the Luminaries (1 En 72-82). He did not indicate any agreements between the apocalypse and Luminaries in his publication. Four manuscripts were found at Qumran containing only the Book of Luminaries with related calendric material (cf. Nickelsburg 2001:9). 
the angelophany of 1 Enoch 70-71' (Reeves 1996:197), are so close that they can hardly be accidental.

Reeves (1996) underscored several explicit correspondences linking 1 Enoch 71:3-4 and the Manichaean Apocalypse:

Enoch's heavenly voyage, the archangel Michael as revelatory agent and tour guide, a reference to the expression 'ends of (the) heaven(s)', even though its precise significance differs in each text, and the heavenly luminaries (i.e., sun, moon, planets) as one of the featured sights of his tour. (p. 193)

Reeves did not indicate any agreements of the Apocalypse with the Book of the Luminaries (1 En 72-82) in his publication, only one with the Book of Dream Visions (reference to seven 'white men' and 'seventy shepherds' in 1 En 90:21-22) and only one in the Epistle of Enoch (books written by Enoch in 1 En 106:19). All of these refer to people with official status.

With regard to the Book of the Watchers (1 En 1-36), particularly the journeys of Enoch (1 En 12-36), Reeves (1996:197) referred to Enoch's third tour of the cosmos (1 En 20-36), in which Michael identifies the Tree of Life (1 En 23-25), the joys of the righteous (1 En 24:6-25:7), Enoch's ascent-experience depicted in 1 Enoch 39:3, and the four-fold division of the world to come (the structuring of Sheol as found in the Greek version of 1 En 22:2). All of these references are again found in the section of Enoch's third journey (1 En 20-36; cf. Apocalypse of Enosh above). As with the apocalypse of Enosh above, all of these references deal with either strange phenomena in the cosmos (strange trees, rivers, wind directions, ascent experiences), or the eschatological destiny of people.

The 'most pertinent episode(s)' (Reeves 1996:191) with regard to the Apocalypse of Enoch can be found in 1 Enoch 70-71 (Enoch's Book of Parables or Similitudes). It tells about Enoch's mode of travel to the supernal regions (1 En 39:3, 52:1, 70-71, 71:3-4), ${ }^{19}$ what Enoch is shown (39:4-5), the luminaries during his heavenly tour (39-41) and God's punishment (41:2), the fallen rulers and mighty ones in eternal darkness (63:6) and the rebellious angelic Watchers at the End of Days (54:5-6, 67:4-7). The focus falls upon strange cosmic phenomena and people divided into the righteous and the transgressors.

\section{The Manichaean Myth}

Manichaeism eventually evolved from the work of its founder Mani. Heuser and Klimkeit (1998:4) ${ }^{20}$ called the basic axioms ${ }^{21}$ of the teaching of Manichaeism 'the Manichaean Myth'. ${ }^{22}$

19.Reeves (1994:176) indicated a close affinity between Manichaean texts and Jewish Hekhalot texts. Elchasai was 'conversant with certain strands of Merkavah (chariot throne) mysticism' (Reeves 1994:177) which were therefore well known to Man as well.

20. Heuser and Klimkeit (1998) used Coptic sources from Medinet-Madi to expound Mani's teachings.

21.Although the Coptic sources do not provide the primal form of Manichaeism, they are to be dated 'relatively close to the time of Mani' (Heuser \& Klimkeit 1998:107). Other original sources of the Manichaean myth are to be studied as well.

22. Klimkeit (1993:5) remarked that Mani's system is preserved in Eastern, specifically Iranian and Central Asian, Manichaeism. It is quite difficult to make a distinction Iranian and Central Asian, Manichaeism. It is quite difficult to make a distinction
between Mani's original teachings and the way they were formulated in later between Mani's original teachings and the way they were formulated
Manichaeism. Cf. also Baker-Brian (2011:96) who used the same term.
Basically, it is a dualistic system 'grounded on the distinction between "the two principles" (Light and Darkness) and "the three times"' (Klimkeit 1993:5-6). The myth includes details of the way in which Light fought against Darkness, how this resulted in the creation of the world and the imprisonment of light particles within the dark elements (cf. Pettipiece 2005:248), and narrates what had gone wrong and shows the way in which the problems facing humankind could be solved (cf. Baker-Brian 2011:96). The two principles of Light and Darkness existed independently from the beginning of time (cf. Heuser \& Klimkeit 1998:7). The central focus of Manichaean religious ideology falls on the problem of evil and redemption of that which is by nature good and pure from the power of evil. Reeves (1992:189) suggests that ' $[t]$ his concern is expressed most clearly in the accounts preserved of Manichaean cosmogonical teaching.' The structural features of Mani's cosmogony 'are essentially identical with those of the earlier Jewish legends' (Reeves 1992:198). Sundermann (2009) indicated that 'the heart and core of the Manichean doctrine is the cosmogony.' Mani's cosmogonical teaching is depicted in terms of the categories of time and space ${ }^{23}$ represented through action (cf. Heuser \& Klimkeit 1998:9).

Mani's cosmogony can be reconstructed from four sources: the 8th century Nestorian bishop Theodore bar Konai's Book of Scholia; the 10th century encyclopaedia of knowledge prepared by al-Nadim entitled 'Kitab al-Fihrist'; several Middle Persian and Sogdian fragments recovered from Turfan, and some allusions to cosmogonical events in Coptic Manichaean literature (cf. Reeves 1992:188-189).

The temporal structure of Mani's cosmogony is based 'on the principle of stages of emanation ..., which correspond respectively to a cosmological action' (Heuser \& Klimkeit 1998:6). According to Sundermann (2009) the eschatology of the Manichean myth 'received inspirations from other religions, mainly from Zoroastrianism and Christianity'. Similar motifs are accumulated, structured as the alternating sequence of dark periods on the one hand and periods of relief on the other. Time is expressed by a division of the mythic events into three temporal phases or moments - beginning, middle and end, called the 'teaching about the three ages' (Heuser \& Klimkeit 1998:18). All cosmogonic events are divided into three distinguishable phases which correspond to the levels of these three consecutive stages of emanation. The first stage is represented by the figure of the Primal Man. The second stage is characterised by the action of the Living Spirit. In the third - the stage of emanation - the Third Envoy appears. The creation of the world is concluded with the creation of humankind (cf. Heuser \& Klimkeit 1998:25).

Right from the beginning God and Satan, Light and Darkness, Spirit and Matter stood over against each other. God's aim is to distil Light from Darkness. Man's task is to assist to bring about this separation so that evil can eventually be vanquished. Guided by the 'Nous' sent from God, man uses his heavenly knowledge to take part in this 23.Klimkeit (1993:241) remarked that 'cosmogonic and eschatological texts were often closely related'. 
process. This development unfolds in a cosmological drama with cosmic dimensions (cf. Klimkeit 1993:6). It entails an all-encompassing cosmology, in which ethical and spiritual principles are associated with concepts of substance (cf. Klimkeit 1993:6). Man has to understand his existence and destiny within this setting of cosmos and eschatology (cf. Klimkeit 1993:35).

The cosmological setting is depicted in terms of '[v]ivid and forceful images like poisonous springs, smoky fog, and burning fire' (Klimkeit 1993:35). Ten heavens and eight earths were fabricated by those entities responsible for demiurgic activity. At various strategic points in this created cosmos the five 'sons' of the 'Living Spirit' keep watch posts. The Great King of Honour lives in the seventh heaven from where he keeps guard over the entire celestial structure. Klimkeit (1993) remarked that a:

book of drawings, which is unfortunately lost, would no doubt have helped us to understand many puzzling points ... talking on such enthralling subjects as the Eight Earths, the Exterior Hells, the Three Wheels, the Seven Great Columns, the posture of Atlas, the Giant of the Sea, the Veins of Connection, the Column of Glory. (p. 223)

At some point in history 200 archons escaped from heaven and fled to earth. They engendered giants as progeny. These giants engaged in different forms of lawless behaviour, instructed humans in various types of esoteric knowledge. This resulted in rebellion and ruin on earth. Four archangels 'were dispatched to sequester the rebellious archons "beneath the mountains" and to destroy their monstrous children in order to repair the damage produced by this revolt' (Reeves 1994:186).

It is obvious that 1 Enoch 6-11 (in whatever form it had then, or another Giant tradition) formed the foundation for at least a part of the Manichaean cosmogony. It not only influenced the succession of events in Mani's presentation, but also the content of his cosmogonical narrative (cf. Reeves 1992). This can be seen in the dualistic setting:

in both narratives, the role of visual perception of beauty and the lust for mixture which this sight engenders, the calamitous results of the ensuing mixture, the affliction of the mixed elements alongside the corruption of the surrounding environment, the dispatch of emissaries to remedy the distress that has been created, and the concern for renewal to a previously unsullied state of existence. (p. 195)

\section{Enoch's influence on Mani}

As Mani used a wide variety of sources to formulate his ideas, it is difficult indeed to isolate Enoch's influence on Mani's thinking. Baker-Brian (2011:22) referred to a 'cultural triangulation of Semitic, Greek and Iranian influences'. Diverse religious and cultural forms from 3rd century Mesopotamia played a role in his theological development. The fragmentary character of the documents available to us also contributes to restricting us in showing the traces left behind by Enochic thinking in Mani's works (cf. Baker-Brian 2011:88).
The obvious dualistic character in Mani's legacy cannot be attributed to Enochic influence only. The similarity between Mani's cosmogony and Zoroastrianism and Gnostic writings indicates a lesser influence from Enochic tradition than is usually presumed (cf. Reeves 1992:185-206; Sundermann 2001). The constant battle between good and evil is more Zoroastrian than Enochic.

Mani got his cyclical idea of prophetology from the Alchaesites. He presented himself as the last in the chain of prophets (cf. Heuser \& Klimkeit 1998:237). However, his predecessor prophets were not the Hebrew prophets, but rather Old Testament antediluvian figures like Shem, Enosh, and Enoch (cf. Heuser \& Klimkeit 1998:111) interpreted as prophets and transformed to fit his specific system (cf. Heuser \& Klimkeit 1998:190). Due to his antinomianism he had no use for the Mosaic Law nor the 'True Prophet tradition' (Frankfurter 1997:65). Influenced by the Marcionite Christian churches of Mesopotamia and Syria he interpreted Paul as teaching 'a distance between the Gospel of Jesus from the legalism of Jewish traditions' (Baker-Brian 2011:54). He understood Jewish apocalypses and their seers independently of the Jewish biblical tradition (cf. Frankfurter 1997:65). He rather presented these predecessor antediluvian figures (to whom different writings were attributed in his time) as 'ecumenical-pan-Mediterranean culture-heroes' (Frankfurter 1997:66). He simply adjusted the antediluvian traditions to harmonise with his dogmas (cf. Reeves 1992:195).

The presence of apocalyptic texts in Mani's writings indicates that Mani adopted and transformed key works of Jewish pseudepigrapha. He did this to enhance his claim as divine prophet. Although integrated very skilfully, imagery drawn from Jewish-Christian traditions, especially from apocalyptic literature, is still obvious in his writings. He made use of those parts of Jewish apocryphal texts 'which treated of the pre-Jewish history of mankind, i.e. the time of the patriarchs before Abraham' (Sundermann 2009). Traces of these are overwhelmingly found in the beginning and middle phases of Mani's cosmogony. A tendency can be found in Mani's works for 'shifting myths back to earlier stages in the Vorzeit' (Baker-Brian 2011:107). As already remarked, the Jewish Enoch writings were very probable one of the sources of Mani's astronomical and calendrical ideas (cf. Sundermann 2001). Ethiopian Enoch does not have any refined chronological scheme, but Mani inserted Enochic material into the first phases of the 'three times' of his chronological program of stages of emanations.

When he used apocalyptic traditions linked to antediluvian patriarchs like Adam, Seth, Enoch, and Shem, Mani gave preference to the figure of Enoch. Mani used themes and motifs drawn from Enochic literature not only to bolster his ulterior prophetic position, but to formulate his cosmogony in terms of persons and places.

It seems that Mani focused on especially two categories in the Enochic tradition. By far most of the allusions, motifs and scenes identified by researchers, deal with the 
depiction of personages or with cosmic places, and very often both. Characters like giants in 1 Enoch 6-11 (the Rebellion of the Watchers), the righteous in 1 Enoch 37-71 (Book of the Parables) and men in white clothes in 1 Enoch 83-90 (Book of Dream Visions) attracted Mani's attention. ${ }^{24}$ Phantasmagorical scenes from Enoch's third journey eastward (1 En 20-36), the Book of Parables (1 En 37-71) and the Book of the Luminaries (1 En 72-82) are represented in the works of Mani.

The rebellion of watchers described in Manichaean tradition overlaps with the fall of the watchers narrated in the Enochic sources. Mani was particularly interested in the role of the Giants in this rebellion narrative. Keeping in mind the issue of relationship to other forms of the Book of the Giants discussed above, we can agree with Baker-Brian's (2011:107) statement that the saga of the rebellion of the watchers was taken over 'by incorporating it in a specific sense into his cosmogony as a description of the watchers' [= the demons] rebellion against the King of Honour'. To be in line with the developing dogmas of Manichaean belief, Ethiopian Enoch's descent of the watchers from above is inverted by Mani to depict the forces of Darkness ascending for the purpose of union. The Enochic substrate had been adjusted (cf. Reeves 1992:195). In Mani's spatial orientation evil cannot come from above. In his dualistic thinking the realm of Light is above and the realm of Darkness below. They are totally separated. No evil substance, quality, or tendency can come from the realm of Light. The evil of Darkness existed independently and coeternal with the Light. Unlike the watchers who descended to earth in order to satiate their lust, the evil in the Manichaean myth was ascending from its own world to begin its assault on the realm of light (cf. Baker-Brian 2011:107).

Mani related hardship and suffering in the world to the corrupting influence of evil (cf. Baker-Brian 2011:106, 118). The legend of the Giants enabled him to identify the wicked Watchers of Enoch with captive archons from the Realm of Darkness. In his dualism and materialistic view of the universe a constant battle is forged between good and evil. The supra-temporal conflict between ruling supra-temporal elites causes men to have become imprisoned in a hostile material world. This legend, therefore, made it possible for Mani not only to identify the origin of evil and the nature of sin in the world, but to also demarcate the goodness of God from all evil (cf. Baker-Brian 2011:107).

\section{Baker-Brian (2011) remarked that:}

the lore of the Enochic tradition was likely to have been of an even greater influence on the construction of Mani's ideas concerning the goodness of God [than] the origin of evil and the nature of sin. (p. 87)

But also the Enochic tradition on righteous people played a role in Mani's thinking. Especially from the Book of Parables (1 En 37-71) Mani took over the depictions of those belonging to God. These included Enoch's ascent to heaven (1 En 39:3)

24.Cf. Reeves's (1999:163, n. 63) remark above that Mani's unique teaching about demons fallen from heaven can be traced back to Jewish Enoch literature. where he saw the dwellings of the holy and the resting places of the righteous (1 En 9:4); the way Enoch was raised on the chariots of the wind ${ }^{25}$ (1 En 70:2) set between two winds (1 En 70:3) and how the archangel Michael took him by his right hand and raised him up (1 En 71:3). In anticipation of the judgment Enoch saw the 'dwelling places of the chosen and the dwelling places of the holy ones' (1 En 41:2) (Nickelsburg \& VanderKam 2004:55) - another idea taken over by Mani.

Reeves (1992) was of the opinion that:

the Jewish legend about the coming of the Watchers and the deeds of the Giants played a decidedly fundamental role in the origin, structure, and development of Mani's cosmogonical teaching. (p. 185)

The Enochic legend of the Watchers and the Giants was even a 'cornerstone of his theological speculations' (Reeves 1992:207) playing 'a central role in the formation and elaboration of Mani's distinctive world-view' (Reeves 1992). These legends served:

as the major structural element in Mani's exposition of the events which led to the creation of the physical cosmos, and as such, remains a paradigm for Mani's subsequent depictions of the hostile intercourse between the realms of Light and Darkness. (p. 207)

This view ignored the fact that Mani fused together Jewish and Iranian legendary material ${ }^{26}$ into his own chronologicdualistic design (cf. Baker-Brian 2011:87).

Next to using the Enochic myth and the lore of the Giants as a springboard for developing his own ideas, Mani was probably attracted to the Enochic legend for its religious value. Baker-Brian (2011) summarised Stroumsa's (1984) ideas in this regard. The material either prompted Mani 'to develop a Gnostic understanding of the giants' (Baker-Brian 2011:88) or present an exegesis of the original biblical text from Genesis (Gn 6). According to Baker-Brian (2011:88) Mani's 'self-awareness as an apostle of light' meant that he could 'take over and complete a longstanding work of a legendary nature in a manner not dissimilar to his appropriation and reimagining of certain gospel texts, as, evidenced in his Shabuhragan'.

A second category that seemed to have attracted Mani's attention, probably even more than characterisation, was that of localisation. ${ }^{27}$ Reeves (1994:189) indicated several correspondences between the narrative of Enoch's Journey eastward (1 En 20-36) and Manichaean texts. Luminosity marks both Enochic Paradise and its Manichaean counterpart. In both, different from Genesis 2-3, the Paradise has a supernal locale. Whilst the Enochic tree possesses an

25.Typical Hekhalot texts with strands of Merkavah (chariot throne) mysticism (cf. Reeves 1994:176-177).

26.Baker-Brian (2011:87) referred to sources like Gnostic writings (the Paraphrase of Šem), the Aramaic two giants Ohya and Ahya - the giant offspring of Shemihaza, and Sahm the giant (Kavi) and Pat-Sahm in the Sogdian version of the work.

27.Cf. Klimkeit's (1993:6) remark above that Mani presented an all-encompassing cosmology, in which ethical and spiritual principles are associated with concepts of substance. 
indescribably pleasant fragrance, aroma of the tree of life is lacking in the Manichaean fragments.

The supernatural ${ }^{28}$ landscape described in the Books of Enosh and of Enoch indicates obvious relationship with the places Enoch visited as described in his third journey (1 En 20-36). In the section 'The Mountain of the Dead' (Nickelsburg \& VanderKam 2004:42-43; 1 En 22:1-14) 'a great mountain with huge pits that serve as repositories for the souls of the deadboth good and evil' (Nickelsburg 2001:102) is depicted. The scene is one of four hollow places, cosmological pits and a mountain of hard rock. The description of high mountains is found in 1 Enoch 24:2-25:7, 25:3, 28:1-32:6 and 34:1 - a depiction taken over by Mani in his cosmogony linking cosmology with his three-part chronological scheme.

The same type of material regarding place and space is found in the Book of Parables (1 En 37-71). The dwelling place of the holy ones in 1 Enoch 41:2 has been referred to already. In 'The Confession of the Kings and the Mighty' (Nickelsburg \& VanderKam 2004:82-83; 1 En 63:1-12) it is narrated that 'light has vanished from our presence, and darkness ${ }^{29}$ is our dwelling forever' (1 En 63:6). 1 Enoch 67:4-7 refers to 'that burning valley ... in the West by the mountains of gold and silver and iron and soft metal and tin'. Descriptions like these were utilised by Mani in his dualistic cosmogony of evil and good.

From the Astronomical Book of Enoch (Book of the Luminaries) (1 En 72-82) the depiction of the motion of the heavenly luminaries, ... their jurisdiction, their time, their name, their origins, and their months' (1 En 72:1), fitted nicely into Mani's astronomic Turfan M 7981 II and his Shaburagan. The section on the law of the lunar year (1 En 74:1-17; cf. Nickelsburg \& VanderKam 2004:101-103); the narrative on the four quarters of the earth with its seven mountains and seven rivers (1 En 77:1-8; cf. Nickelsburg \& VanderKam 2004:106-107); and the description of the 'sun and ... moon and those who lead the stars of the sky and all those who turn them their work, their times, and their emergences' (1 En 80:1), all of these fitted into Mani's ideas of the universe.

\section{Conclusion}

Mani lived in a world of many ideas that contributed to his unique theology. Obvious relations to the Enochic tradition and its literature can be identified in the works of Mani. This article proposes that Enochic influence can mainly be found in the way First Enoch depicted characters and presented a type of cosmology in which the righteous and the evildoers are allocated to different phantasmagorical places in the universe.

\section{Acknowledgements}

The research for this article has been performed with the support of the National Research Foundation of South Africa.

28.Cf. Klimkeit's (1993:35) description of Mani's use of 'vivid and forceful images'.

29.Cf. Mani's Light against Darkness idea.

\section{Competing interests}

The author declares that he has no financial or personal relationship(s) which may have inappropriately influenced him in writing this article.

\section{References}

Baker-Brian, N.J., 2011, Manichaeism: An ancient faith rediscovered, T \& T Clark International, London.

Böhlig, A., [1947] 2012, 'Die Bibel bei den Manichaern', in P. Nagel \& S.G. Richter (eds.), Die Bibel bei den Manichaern und verwandte Studien von Alexander Böhlig, D Theol. Thesis, Brill, Leiden. (Nag Hammadi und Manichaern Studies, Book 80).

Frankfurter, D., 1997, 'Apocalypses real and alleged in the Mani Codex', Numen 44, fasc 1, 60-73.

Henning, W.B., 1943, 'The Book of the Giants', Bulletin of the School of Oriental and African Studies 11, 52-74. http://dx.doi.org/10.1017/S0041977X00071214

Heuser, M. \& Klimkeit, H-J., 1998, Studies in Manichaean literature and art , Brill, Leiden. (Nag Hammadi and Manichaean Studies, XLVI).

Hutter, M., 1992, Manis kosmogonische Shabuhragan-texte, edition, kommentar und literaturgeschichtliche einordnung der manichaisch-mittelpersischen Handschriften M 98/99 I und M 7980-7984, Otto Harrassowitz, Wiesbaden.

Klimkeit, H.-J., 1993, Gnosis on the silk road: Gnostic texts from Central Asia, transl. H-J. Klimkeit, Harper, San Francisco.

Milik, J.T., 1971, 'Turfan et Qumran: Livres des Geants juif et manicheen', in G. Jeremias, H-W. Kuhn \& H. Stegemann (eds.), Tradition und glaube: Das frühe Christentum in seiner umwelt, pp. 117-127, Vandenhoeck \& Ruprecht, Gottingen.

Milik, J.T., 1976, The Books of Enoch: Aramaic Fragments from Qumran Cave 4, Clarendon Press, Oxford.

Nickelsburg, G.W.E., 2001, 1 Enoch 1, Fortress, Minneapolis.

Nickelsburg, G.W.E. \& VanderKam, J.C., 2004, 1 Enoch: A new translation, Fortress, Minneapolis.

Orlov, A.A., 2007, 'Roles and titles of the seventh Antediluvian hero in the Parables of Enoch: A departure from the traditional pattern', in G. Boccaccini (ed.), Enoch and the
Messiah Son of Man: Revisiting the Book of Parables, pp. 110-136, Wm. B. Eerdmans Messiah Son of Man: Revisiti
Publishing, Grand Rapids.

Pettipiece, T., 2005, 'A church to surpass all churches. Manichaeism as a test case for the theory of reception', Laval Théologiqueet Philosophique 61(2), 247-260. http:// dx.doi.org/10.7202/011816ar

Reed, A.Y., 2009, 'Beyond revealed wisdom and apocalyptic epistemology, early Christian transformations of Enochic traditions about knowledge', in C.A.H. Evans \& D.H. Zacharias (eds.), Early Christian literature and intertextuality, vol. 1, pp. 138-164, T\&T Clark, London.

Reeves, J.C., 1992, Jewish lore in Manichaean cosmogony: Studies in the Book of Giants traditions, Hebrew Union College Press, Cincinnati.

Reeves, J.C., 1994, 'Jewish pseudepigrapha in Manichaean literature: The influence of the Enochic library', in J.C. Reeves (ed.), Tracing the threads: Studies in the vitality of Jewish pseudepigrapha, pp. 173-203, Scholars Press, Atlanta.

Reeves, J.C., 1996, Heralds of that good Realm: Syro-Mesopotamian Gnosis and Jewish traditions, Brill, Leiden.

Reeves, J.C., 1999, 'Exploring the afterlife of Jewish pseudepigrapha in Medieval Near Eastern religious traditions: Some initial soundings', Journal for the Study of Judaism in the Persian, Hellenistic and Roman Period 30, 148-177. http://dx.doi. org/10.1163/157006399X00037

Richter, P. \& Nagel, S.G. see Böhlig, A., [1947] 2012.

Stroumsa, G.A.H., 1984, Another seed: Studies in Gnostic Mytholog, Brill, Leiden. (Nag Hammadi Studies: The Coptic Gnostic Library 24).

Sundermann, W., 1984, 'Ein weiteres Fragment aus Manis Gigantenbuch', Acta Iranica 23 Second Series IX, 491-505. (Also published in Duchesne-Guillemin, J., 1984, Teheran/ Liege, 491-505).

Sundermann, W., 1985, Ein manichäisch-soghdisches Parabelbuch, mit einem Anhang von Friedmar Geissler über Erzählmotive in der Geschichte von den zwei Schlangen, Akademie Verlag, Berlin. (Berliner Turfantexte, 15).

Sundermann, W., 1989, Another fragment of Mani's, Book of the Giants' (in Russian with English summaries), Vestnik Drevnej Istorii 190, H. 3, 67-79.

Sundermann, W., 1992, s.v. 'Cologne Mani Codex', in Encyclopædia Iranica, vol. 5, fasc. 1 , pp. 43-46, viewed 02 October 2013, from http://www.iranicaonline.org/articles/ cologne-mani-codex-parchment

Sundermann, W., 1993, s.v. 'Cosmogony and Cosmology iii. in Manicheism', in Encyclopaedia Iranica, vol. 5, fasc. 3, pp. 310-315, viewed 02 October 2013, from $\mathrm{http}: / /$ www.iranicaonline.org/articles/cosmogony-iii

Sundermann, W., 2001, s.v. 'Giants, the Book of', in Encyclopaedia Iranica vol. 10, fasc. 6, pp. 592-594, viewed 26 October 2013, from http://www.iranicaonline.org/articles/ giants-the-book-of

Sundermann, W., 2009, s.v. 'Manicheism: General survey', in Encyclopaedia Iranica, viewed 30 October 2013, from http://www.iranicaonline.org/articles/manicheism-1 general-survey, (Originally published: July 20, 2009).

Tardieu, M., 2008, Manichaeism, transl. M.B. DeBevoise, University of Illinois Press, Urbana/Chicago.

Van Oort, H., 2006, 'Augustine and Manichaeism: New discoveries, new perspectives', Verbum et Ecclesia 27(2), 709-728. http://dx.doi.org/10.4102/ve.v27i2.172

Van Oort, J., 2009, 'Manichaeism: Its sources and influences on western Christianity', Verbum et Ecclesia 30(2), Art. \#362, 5 pages. http://dx.doi.org/10.4102/ve.v30i2.362 